Revue interdisciplinaire des études canadiennes en

France

$80 \mid 2016$

Le Canada et la Grande Guerre

\title{
Bearing the Burdens of Their Elders: English- Canadian Children's First World War Red Cross Work and Its Legacies
}

Porter le fardeau des aînés: le travail bénévole des enfants canadiens durant la Première Guerre et au-delà

\section{Sarah Glassford}

\section{(2) OpenEdition}

\section{Journals}

Electronic version

URL: http://journals.openedition.org/eccs/695

DOI: $10.4000 /$ eccs.695

ISSN: 2429-4667

\section{Publisher}

Association française des études canadiennes (AFEC)

\section{Printed version}

Date of publication: 1 June 2016

Number of pages: 129-150

ISSN: 0153-1700

\section{Electronic reference}

Sarah Glassford, "Bearing the Burdens of Their Elders: English-Canadian Children's First World War Red Cross Work and Its Legacies », Études canadiennes / Canadian Studies [Online], 80 | 2016, Online since 01 June 2017, connection on 21 December 2020. URL : http://journals.openedition.org/eccs/ 695 ; DOI : https://doi.org/10.4000/eccs.695 


\title{
BEARING THE BURDENS OF THEIR ELDERS: ENGLISH-CANADIAN ChILdREN's First World WAR REd Cross WORK AND ITS LEGACIES
}

\author{
Sarah GLASSFORD \\ University of New Brunswick
}

\begin{abstract}
This article explores the untold history of English-Canadian children's First World War work for the Canadian Red Cross Society. First it examines young people's material and symbolic contributions, then follows the legacies of children's war work through to the Second World War. It also highlights the connection between youthful war work and the interwar Junior Red Cross (focused on health, service, and citizenship). English-Canadian youth did not cause the conflict, but through their involvement with the Canadian Red Cross Society successive generations of them bore the war's tangible and intangible burdens.

Cet article s'intéresse à l'histoire inédite du travail des enfants canadiens-anglais au sein de la Société canadienne de la Croix-Rouge, durant la Grande Guerre. On examinera d'abord les contributions matérielles et symboliques des jeunes, puis nous en suivrons l'héritage jusqu'à la Seconde Guerre mondiale. L'article fait le lien entre les activités des jeunes de la Croix-Rouge dans l'entre deux-guerres (qui étaient surtout tournées vers la santé, le service, et la citoyenneté) et l'œuvre accomplie durant la Première Guerre. Ces jeunes n'avaient rien à voir avec le conflit, mais à travers leur implication au sein de la Croix-Rouge des générations successives ont continué à porter l'héritage de ce lourd passé.
\end{abstract}

In October 1915, registered nurse Emily Holmes-Orr organized eleven boys and girls under the age of thirteen from the hamlet of Northgate, Saskatchewan into a formally chartered branch of the Canadian Red Cross Society (CRCS). Northgate is located on the Canada-United States border, and at that time lacked the customary institutions of both school and church. Holmes-Orr recalled in the 1930s that, in the absence of these institutions, "the older people" in the hamlet believed Red Cross work "would bring something unselfish into the lives of the children. It would train them, no matter how tiny they were, to help bear the burden their country was bearing ${ }^{1}$."

Similar references to children's voluntary war work for the Red Cross and other war charities began appearing in newspapers mere weeks into the First World War (1914-18). By the end of the war, Canadian youth had proved themselves worthy and vital sources of much-needed money and labour. By drawing on fragmentary surviving evidence, this article explores the untold history of English-Canadian children's wartime work for the Canadian Red

${ }^{1}$ Editorial (1938), The Canadian Red Cross Junior, 17:3, p. 3. 


\section{Sarah GLASSFORD}

Cross Society. It considers young people's symbolic contributions (particularly an image of "all ages" support) to both Red Cross work and the wider war effort, as well as their specific material contributions of goods, money, and voluntary labour. The article then follows the legacies of children's war work through to the Second World War (1939-45) in order to assess their long-term impact.

English-Canadian children bore the war-related burdens of their elders three times, from the 1910 s to the 1940s. First, they were called upon to help shoulder the load of voluntary war work in a global conflict not of their own making. Canadian society during the First World War was marked by intense social pressures on the home front. For those ineligible to enlist in the military, this included the pressure to serve and sacrifice for victory in other ways. At the same time, early-twentieth century Canadian adults understood children and youth as able workers and citizens-in-the-making. These two factors combined with young people's own enthusiasm and interest in the war situation to actively engage children and youth in wartime voluntary work. Young people were further burdened during the 1920s and 1930s by the heavy weight of interwar adult idealism, which saw in the children of these decades the potential to redeem the world their parents and grandparents had broken.

After the 1918 Armistice, the example of children's Red Cross war work influenced the creation of the interwar Junior Red Cross program, which was meant to create a generation of healthy, service-minded, internationalist children - thereby helping adults atone for the devastation of the First World War. Yet a mere twenty years after its creation, the JRC would in turn ask children to bear the burden of war, when it deliberately mobilized them for voluntary war work in the Second World War. English-Canadian youth did not cause the Great War, but through their involvement with the Canadian Red Cross Society successive generations of them bore both its tangible and intangible burdens.

\section{Beginnings: Young People, War, and the Red Cross}

Only recently has the vast historiography of the First World War extended to include children in any meaningful way, influenced by the growth of children's history as a subfield of its own. Studies covering wartime voluntary work by Annie Campbell on Australian children, Rosie Kennedy on British children, and Charlotte Bennett and Jeanine Graham on New Zealand children, make it possible to consider the Canadian situation in an international 
(and specifically British Commonwealth) context (CAMPBELL 2004; KENNEDY 2014; BENNETT 2014; GRAHAM 2008). Kristine Alexander's chapter on Canadian girls in the Great War, as well as work by Tim Cook, Dan Black, and John Boileau on underage enlistments in the Canadian Expeditionary Force make it clear that young people were active participants in the conflict, on both the home front and the battle front (ALEXANDER 2012; COOK 2008; BLACK and BOILEAU 2013). Susan Fisher's study of Canadian children's wartime reading offers a valuable cultural context for understanding youthful engagement in the war effort, situating their war work in the realm of ideas promulgated by school texts, youth periodicals, and war fiction (FISHER 2011). Yet the experiences of young Canadians in the war remain more unknown than known. Focusing on children's involvement with one voluntary organization allows for a clearer and more detailed picture to emerge of one aspect of young English-Canadians' experiences of the First World War. The Canadian Red Cross Society (CRCS) is an ideal choice because, as Canada's second-largest war charity and leading humanitarian aid organization of the Great War, it was a household name, active in all regions of the country. Its continued role in Canadian society to the present day has produced a relatively substantial archival record of its history, making it possible to successfully trace change over time, and broaden the context in which youthful war work is understood.

The international Red Cross movement began organizing charitable aid to the sick and wounded in wartime with the first Geneva Convention of 1863. Its basic principles, however, were shaped by its Swiss founders Henry Dunant and Gustave Moynier. Dunant's brush with the carnage of the 1859 Battle of Solferino in Italy led him to advocate voluntary societies in each nation trained to provide efficient battlefield aid to the sick and wounded. Moynier's background in philanthropy and social reform made him the architect of the international movement that would convert this vision into reality. Dunant, Moynier, and their colleagues on the International Committee of the Red Cross (ICRC) focused their advocacy and organizational work on adults: monarchs, politicians, diplomats, military leaders, and wealthy philanthropists. Internationally, children would not become widespread participants in Red Cross work until the First World War, but the rhetorical framework for them to do so existed from the beginning. In his influential 1859 book A Memory of Solferino Dunant praised the spontaneous nursing he saw done after the battle by both young girls and older women. He called for men and women, rich and poor, monarchs and servants, writers and generals, "every 


\section{Sarah GLASSFORD}

nation, every district, and every family" to take up the cause of suffering humanity in wartime (HUTCHINSON 1996: 11-12, 17, 20-24).

The Canadian Red Cross Society - Canada's contribution to the array of national aid organizations envisioned by Dunant - was founded in 1896 with a narrow mandate to aid the sick and wounded in wartime. After a modest but successful first humanitarian effort in the South African War (1899-1902) the Society was reorganized in 1909 with an Act of Incorporation by the Canadian parliament that officially recognized it as an auxiliary to the military medical service in wartime. Although the CRCS was small and unprepared for the outbreak of war in 1914 it rapidly expanded thanks to grassroots enthusiasm and women's desire for socially acceptable means of participating in the war effort. By January 1915 the Society was well established as one of the principal channels for Canadians' patriotic support of their enlisted friends, loved ones, and fellow citizens. The Society's ties to the British Red Cross Society and the neutral Geneva-based ICRC gave it access to Canadian sick and wounded in Britain, France, and Belgium, as well as to Canadian Prisoners of War (POWs) in enemy hands. For four years, Canadians gave their time, money, and skills to the Society, allowing it to provide hospitals, ambulances, comforts and recreational facilities, invalid foods, medical supplies, POW food parcels, and a tracing service for the missing and wounded. The war years developed an enduring relationship of trust between Canadians and their Red Cross, established the CRCS as a truly national organization, and led the Society to expand its mandate into peacetime public health work beginning in 1919 (GLASSFORD 2016: ch. 1-4).

The first known instance of young people's involvement with the Canadian Red Cross comes from the South African War. Miss Adelaide Clayton, a teacher of English and Moderns at the Collegiate Institute in St. Mary's, Ontario, organized her female students as the "St. Mary's Maple Leaves" - a club that raised money for the Red Cross. The club sent \$341 to CRCS headquarters from April to June of 1900, $\$ 300$ of it raised by a very successful bazaar. A faded photograph badly reproduced in a magazine 37 years later shows at least 40 high school aged young women (and one boy of 10 or 12 years old in the foreground) formally posed in front of small table-andchair groupings set for tea. At least one Union Jack flag is visible, and many of 
the girls sport a homemade red cross armband over the left sleeve of their blouse or shirtwaist ${ }^{2}$.

The St. Mary's Maple Leaves are of interest not only for being the first and only known youth to work for the CRCS before the Great War, but because even the small amount of surviving information about them conveys striking similarities with young people's later Great War involvement with the Red Cross. First, they were formally organized by an adult, but on her own initiative, not through the CRCS. Second, they were organized through an existing institution - their school. Third, their activities were not significantly different from those of adult Red Cross volunteers. Fourth, their efforts produced substantial results: the $\$ 341$ of 1900 is equivalent to more than $\$ 7,269.00$ today $^{3}$. Fifth, the students' Red Cross work was linked to patriotism (as their name and the decorative flag in the photo suggest) - at least their teacher's patriotism, if not necessarily their own. Miss Clayton explained her decision to start the club as one sparked by her own heritage: since her grandfathers had been English army officers, the Canadian and British participation in the South African War "aroused [her] British blood ${ }^{4}$." All of these characteristics would reappear during the First World War.

\section{The Opportunity of a Lifetime? English-Canadian Youth and the Great} War

As in the South African War, during the First World War the Canadian home front was geographically a world away from the battlefields. However, as Jeanine Graham argues with respect to New Zealand, "distance did not mean detachment," and instead "the dominant ethos was of a collective crusade" (GRAHAM 2008: 431-432). The idea of a total mobilization of the population emerged early in the war. Lord Roberts, one of Britain's most successful nineteenth-century military commanders, stated within the first months of the war that "men and women, young and old, rich and poor, all alike must place everything at the service of the state" [italics added] now that the British Empire was at war with the Central Powers in Europe ${ }^{5}$. Total war required

\footnotetext{
2 “"Maple Leaves' Organized in 1899” (1937), The Canadian Red Cross Junior, 16:9, p. 2; ““Maple Leaves' Worked for Red Cross in the South African War" (1937), The Canadian Red Cross Junior $16: 3$, p. 3.

${ }^{3}$ See Bank of Canada Inflation Calculator, www.bankofcanada.ca , (17 May 2016). The calculator only goes back to 1914 , so the true value today would be even higher.

4 “"Maple Leaves' Worked...” 1937: 3.

${ }^{5}$ Editorial (1914), The Educational Review, December, p. 129.
} 


\section{Sarah GLASSFORD}

everyone's participation, children included, and its ideologies of service and sacrifice permeated virtually all corners of society in the combatant countries (KENNEDY 2014: 2-3; FISHER 2011: 7-8).

Outside of French Canada, where French-Canadians' own history as a conquered people made empire distasteful, Canadian schools of the pre-war decades relentlessly glorified the British Empire and Canada's place within it. This left English-Canadian schoolchildren "primed to patriotically pitch in" when Britain declared war in August 1914 (MILLAR and KESHEN 2010/11: 4). An anonymous primary school teacher in Atlantic Canada inadvertently acknowledged this groundwork in an article about how to talk about the war in the lower grades. "Well we know that the subject must be discussed," she or he wrote, "for the little ones are just as interested in the war news as their elders." Like adults, children picked up war information from a variety of sources, reliable or not, and they were "burning with the desire to communicate said items to their schoolmates, and particularly to the long-suffering teacher." Although some American school districts had decided to avoid the subject of war in the classroom on the grounds that it was too militaristic, this teacher believed it was "the opportunity of a life-time, no matter how deplorable the facts leading up to the event, to show children just how history is made." He or she recommended reading high quality war poems, discussing ideas like valour and patriotism but discouraging hatred and flippancy, teaching about war leaders, and highlighting "the work of the Red Cross and Purple Cross Societies ${ }^{6}$."

Outside the classroom, even more powerful social forces were at work mobilizing children. For example, the students of Charlottetown, Prince Edward Island's Prince Street School sang at a rally in Market Square to raise money for the British Red Cross on 21 October 1915. There they would have heard Colonel Peake's address calling for churches and communities to create "dishonour rolls" for men who did not enlist in the military (rather than celebrating those who did) (DALEY 1981: 24). His blatant call for universal sacrifice and service could scarcely have been lost on his youngest listeners. Norah Lewis's study of English-Canadian children's wartime letters to the children's pages of Canadian newspapers revealed overt expressions of patriotism and a firm belief in the justice and necessity of Canada's involvement in the war (LEWIS 1995: 196). These youthful letter-writers had taken to heart the lessons of their elders, as promoted by Empire Day

\footnotetext{
6 "Children and the War" (1915), The Educational Review, March, pp. 208-209. The Purple Cross Society raised money for animal welfare during the Great War, especially for war horses.
} 
celebrations, school texts, patriotic poetry, war fiction, and the children's pages of these same types of newspapers (FISHER 2011: ch. 1-7; PALKA 2012: 52). Rosie Kennedy further notes that although children were mobilized for war service by adults, they also mobilized themselves: "invented games and imaginative connections were made by children, alone and with each other, which contributed towards their understanding of the war and defined their relationship to it." She argues that since "the war entered every aspect of children's lives" - home, school, community, church, work, play, entertainment - it is not surprising that "they took the opportunity to contribute in the only ways they could" (KENNEDY 2014: 8, 19).

Within this context of total war, English-Canadian children, like children in New Zealand and Britain, participated in the home front side of the war in a variety of ways. These included raising money or creating comfort items for patriotic organizations, relief societies, and other war charities, purchasing war stamps and advertising war bonds, participating in thrift campaigns or victory gardening, writing letters to servicemen, composing patriotic essays, regulating their own behaviour and emotions so as to ease the burden on their parents and teachers, and taking part in soldier send-offs and welcome-home festivities, recruiting meetings, patriotic concerts, and other public spectacles related to the war (GRAHAM 433-436, 438; BENNETT 2014: 23-28; KENNEDY 2014: 83-119; ALEXANDER 2012: 185-189; FISHER 2011: 31-50; PALKA 2012: 52-72; RUTHERDALE 2004: 212; MILLAR and KESHEN 2010/11: 4-8).

Although the social and cultural context of total war is crucial to understanding the mobilization of young people for these types of wartime involvement, another element is important to keep in mind. In 1910s Canada, the active labour of children - either unpaid at home, or for wages outside of it - was not at all unusual, and more or less taken for granted among the rural and working classes. Although child-savers and other social reformers had made important in-roads toward regulating this work through child labour laws and compulsory school attendance legislation, young people still did farm labour, lived-in as domestic servants, worked in coal mines and factories, apprenticed in the trades, sold newspapers and shone shoes in the streets, cared for younger children, and filled a host of smaller needs, independently or alongside adults (BULLEN 1986: 163-187; FISHER 2011: 32). Since child labour was not seen as inherently bad in and of itself, it was therefore practically a foregone conclusion that young people would participate in voluntary war work. During the First World War young English-Canadians were mobilized alongside adults 


\section{Sarah GLASSFORD}

by a society that recognized childhood as a distinct life stage but did not yet believe this precluded children's active participation in either waged or unwaged labour.

\section{Sifting Through the Fragments: Which Young People Did Red Cross Work and Why?}

A combination of bottom-up child initiative and top-down adult leadership seems to have fuelled children's Great War Red Cross work. The scarce and fragmentary nature of the surviving evidence makes it impossible to provide great detail about any single aspect or example, or to engage in any kind of systematic analysis of the age, gender, class, or racial/ethnic profile of the youth who engaged in it. However, a few basic points can be sketched here. First, the students of at least two residential or day schools for Aboriginal children participated in Red Cross work: an article in the CRCS Bulletin noted that a \$21.00 donation from Carcross, Yukon in 1917 had been "largely subscribed by Indians and the children in the Indian Boarding School," while the File Hills Indian School was among the many Saskatchewan Junior Red Cross branches formed in 1918. The File Hills youth raised \$122.10, significantly more than many of the Euro-Canadian branches ${ }^{8}$. Second, Red Cross war work required a certain amount of leisure time in which to volunteer, making it less feasible for those (for instance, older teens or rural youth) who had to work in paid employment or on farms. Nonetheless, working young people still participated. The Edmunston, New Brunswick Red Cross branch members proudly reported that they were formed in December 1917 by fifteen young women who "were all working girls." The small branch managed to give a concert, sew and knit supplies, and pack Christmas stockings for soldiers before the end of the war (CLEMENTS 1919: 60).

Third, although the absence of statistics or membership records make it impossible to determine which age groups were most or least active in Red Cross work, word choices and affiliations offer a few clues as to the broader span of ages involved. Both "children" and "young people" are mentioned in connection with the work. Primary schools and Sunday schools (for students aged 5 to 13) as well as high schools (for youth aged 14 to 19) and formal Young Peoples' groups (for those in their teens and early twenties) are all listed as contributors of money or goods. These facts suggest that Red Cross work engaged children from as young as 5 years old, right through to young

\footnotetext{
7 "President "Chief Carry the Kettle"” (1917), Bulletin, 24: March, p. 9.

${ }^{8}$ CRCS (1919), Annual Report for 1918, Toronto: CRCS, p. 145.
} 
adulthood. Fourth, the fact that much Red Cross work was gendered female particularly sewing, knitting, and food preparation - inevitably drew girls into its orbit. Teenaged girls could easily participate in adult women's sewing circles if they wished. An October 1914 story from England, printed in a Canadian Salvation Army Sunday school publication, even presented "playing Red Cross" as little girls' alternative to the boys' playground war games (FISHER 2011: 108-109). However, there is plenty of evidence that boys also worked for the Red Cross during the First World War in large numbers, either through organizations like the Boy Scouts, or in mixed-gender groups. And finally, no positive evidence has been located to indicate that Francophone children participated in Red Cross work - a finding that accords with Francophone adults' less enthusiastic support of the overall war effort than their Anglophone compatriots (MILLAR and KESHEN 2010/11: 2). So, although it is impossible to say conclusively that no French-Canadian youth engaged in Red Cross work (and surely at least a few did), this article extends its arguments only to English-Canadian children.

At different points in the 1930s, the CRCS recognized two separate "founders" of the Junior Red Cross in Canada. They happen to illustrate two common ways children worked for the CRCS. One was Montreal artist and handicrafts promoter May Phillips, who organized a children's auxiliary (an arm's length affiliate of the Red Cross) at Greenfield Park, Quebec (near Montreal) in September 1914. The other was nurse Emily Holmes-Orr, who organized the Northgate, Saskatchewan children in a formal Red Cross branch, as discussed above (EASTON McLEOD 1999: 35; Editorial 1938: 3). Alternately, young people worked through their schools or church groups to raise money that they offered as a one-off donation to a local Red Cross branch, or participated individually or in small groups as part of adult Red Cross auxiliaries and branches. The seemingly widespread integration of youth into adult Red Cross work makes it impossible to get a clear sense of how many young people were involved, how much money they raised, or how many items they knitted or sewed. It also reflects the notion of the war as a national emergency that required everyone's participation: the expectation that children would contribute to the war effort just like their elders likely encouraged the inclusion of young people in adult organizations and activities.

Yet, as Holmes-Orr's recollections about organizing the Northgate children's branch suggest, some adults perceived a value in segregating youth into their own volunteer groups. This value might be moral, as in the Northgate adults' hope that Red Cross work would serve as an object lesson in "the real 


\section{Sarah GLASSFORD}

suffering of those who were so bravely fighting." It could also be quite practical. Novelist L.M. Montgomery's fictional Anne Shirley Blythe (formerly of Green Gables) articulates the latter in Montgomery's 1921 war novel Rilla of Ingleside. "Rilla, don't you think you could organize a Junior Red Cross among the young girls?" Anne asks her 15 year-old daughter in 1914, when Rilla voices her desire to do something useful for the war effort. "I think they would like it better and do better work by themselves than if mixed up with the older people." However, the practical and the moral could blend together. Rilla immediately associates her "Junior Reds" work with her determination to be "as brave and heroic and unselfish" [original italics] as she can (MONTGOMERY [1921] 2010: 69-70). Within the novel as a whole, Montgomery uses Rilla's experiences with the Junior Reds to demonstrate her growing maturity, a trajectory that she further uses to symbolize Canada's coming-of-age in the crucible of war (MCKENZIE 2008: 96-101).

\section{Innocent, Merciful, Capable: The Symbolism of Children's Red Cross} Work

From the distance of a century, the most easily discernible involvement of young people with the CRCS is symbolic. The Red Cross work of children and youth was often heralded as proof of how broad a swath of the population had mobilized in support of the organization. Kristine Alexander rightly emphasizes the importance of gender in wartime propaganda - girls were a cipher for innocence, purity, and all things good (ALEXANDER 2012: 176-177) - but for the CRCS age was an important qualifier on its own merits. Contemporary descriptions of CRCS work often use contrasting pairs to display the organization's wide appeal: women and men, city and country, rich and poor, old and young. A June 1917 editorial did just this in calling for Albertans to support their provincial Red Cross on 2 July: "the woman making a shirt ... in her lonely homestead on the prairies; the children knitting in our schools," as well as "the farmer giving his produce to be sold for the Red Cross; the city man making contribution from a hard earned salary," were said to be "essential links in the great chain" of home front Red Cross work ${ }^{10}$. In this framework children and youth mattered as an abstract concept - age was no barrier to participation or enthusiasm in the great humanitarian mission of mercy - but this "all-ages" representation should not be conflated with either complete agency in young people's participation, nor their access to positions of

\footnotetext{
${ }^{9}$ Editorial 1938: 3.

10 "July $2^{\text {nd }}$ is Alberta's Red Cross Day" (1917), newspaper clipping, scrapbook (marbled cover), box 3, Canadian Red Cross National Archive.
} 
influence in the CRCS. No surviving evidence speaks explicitly about the degree to which young people directed their own efforts, but it seems reasonable to infer a degree of adult supervision and/or direction at least for children under the age of 12 . No youth were active in the provincial or national executives of the CRCS, although at the branch and classroom level it is quite possible that young people exerted significant influence over their own activities.

Symbolically, what young Canadians did for the Red Cross mattered relatively little. The fact that they did something was the crucial point. In the wider realm of the Canadian war effort, as Fisher notes, the presence of children "lent their innocence to the enterprise of war" (FISHER 2011:10). The humanitarian mission of the Red Cross needed no such sanitization, but children's perceived innocence nonetheless bolstered the established image of the organization's work as a caring, life-sustaining endeavour (GLASSFORD 2008: 221). "Some day," wrote the editor of the Saint John Standard children's page in September 1918, "the children of all lands under the Red Cross will teach the grown up people the ways of understanding and of friendship" (PALKA 2012: 92). This theme would find traction in the revamped and expanded Junior Red Cross movement of the 1920s and 1930s.

The symbolic mobilization of children as capable, active workers in the war offers a striking counterpoint to the more common deployment of children as victims, whether real, imagined, or potential. The rumours of German atrocities in Belgium offer the best contemporary example: children with severed hands and babies bayonetted or tossed into wells by rampaging soldiers surely represented the ultimate image of vulnerable innocence (FISHER 2011: 8). Canadian children were well-versed in these atrocity stories, and adults "heavily encouraged" them to raise money or engage in other work for the Belgian relief effort (PALKA 2012: 78-79), which they did with great gusto. Two very different images of childhood converged, as the perceived victimization and vulnerability of Belgian children offered Canadian children an opportunity to demonstrate their contrasting strength and ability in this case, by raising funds to help others.

\section{Child Labour: Young People's Active Engagement in Red Cross Work}

Although young people played important symbolic roles in wartime, they were also actively engaged in home front war work. For instance, the reliance of war charities like the CRCS upon social events and public 


\section{Sarah GLASSFORD}

spectacles for much of their fundraising and publicity offered children a chance to participate as spectators and consumers. Young girls in costume as "Red Cross nurses" made decoratively appealing additions to any event, and thus were frequently deployed by adult event organizers. In a similar vein, Charlottetown's Red Cross Fancy Dress Carnival of August 1915 was guaranteed to appeal to Prince Edward Island's youth, since it combined the fun of dressing-up with the hoopla of a parade. Throngs of adults and children lined the streets as "gorgeously bedecked carriages carried elegantly costumed children"11 along the parade route and toward the parks and squares where costumed young women held Maypole dances. The event organizers also deliberately involved children in competitions, offering prizes for the best costumes and the most money collected in donations (DALEY 1981: 21).

The tangible results of children's fundraising efforts first appear in the CRCS annual reports for 1915 and 1916, when several schools and Sunday school groups in Ontario and Prince Edward Island are listed as having each donated sufficient funds to purchase a motor ambulance for use overseas ${ }^{12}$. As the report from Netherwood School for Girls in Rothesay, New Brunswick makes clear, youthful contributions were by no means negligible: in addition to their regular school work and extracurricular activities, the girls raised $\$ 1,049.14$ for their own and others' Red Cross work, and sewed or knitted 2,952 individual articles (including socks, handkerchiefs, towels, bandages, and garments) between September 1916 and April 1919 (CLEMENTS 1919: 76).

The New Brunswick Division of the CRCS peppered the written history of its wartime work with references to youthful engagement. Moncton branch had a formal Junior Red Cross wing in 1917-18 that was quite active in fundraising, as did the Andover and Perth branch. In McAdam, "several children held a parlour concert and gave the proceeds to the Red Cross." Schools, girls' clubs, Young Peoples' Associations, Sunday schools, and unorganized assortments of children are listed among the hundreds of donors to general Red Cross funds, as well as the sewing circles affiliated with the Red Cross. Four groups of youth were among those who donated $\$ 50$ for a bed at one of the CRCS-built hospitals in Britain and France over the course of the war. Many more young people are probably hidden within the larger groups represented by church- and place-based entries like "Trinity Episcopal Church"

${ }^{11}$ Presumably the carriage-riding, costumed children belonged to the city's elite, while those watching from the street were of humbler origins.

${ }^{12}$ CRCS (1916), Annual Report for 1915, Toronto: CRCS, p. 52; CRCS (1917), Annual Report for 1916, Toronto: CRCS, p. 65. 
or "Gagetown." Young New Brunswickers were particularly active in collecting and sorting/grading sphagnum moss, which the CRCS needed to produce bandages in 1918 when there was a global shortage of absorbent cotton (CLEMENTS 1919: 9-12, 20-27, 42-43, 72, 75, 89).

Young people proved to be as versatile and creative as their parents and grandparents when it came to making the most of local resources and opportunities to contribute to Red Cross work. Like their New Brunswick counterparts, Nova Scotia youth waded through cold, wet, coastal bogs to gather moss, with Girl Guides, Boy Scouts, YMCA boys, schoolteachers with their pupils, and young people from local communities all pitching in. POWs were also a favourite focus for youthful Nova Scotian Red Cross work, with up to 22 schools and Sunday schools covering the costs of Red Cross food parcels for their "adopted" POWs by $1917^{13}$. Schoolchildren in Victoria, British Columbia threw themselves into collecting waste paper which they then sold for recycling purposes. Of the nearly $\$ 4,000$ they raised during the war years, a little over $\$ 1,300$ went into the general CRCS war fund, followed by thousands more raised specifically to buy ambulances for service in France. Ontario children grew and sold enough potatoes in 1917 to pay for a CRCS ambulance of their own, while schoolchildren in Margaret, Manitoba grew potatoes in their schoolyard and donated the proceeds to a local Red Cross sewing circle (FISHER 2011: 35-37). Standard Great War-era fundraising activities like tag days, bake sales, teas, bazaars, and patriotic concerts would also have been employed by children. All in all, the surviving evidence makes it clear that, although naturally there would have been many examples of "occasional slackers and resentful foot-draggers" (FISHER 2011: 33) among EnglishCanadian children working for the CRCS, enthusiasm and/or dutiful dedication were also present in abundance.

Mobilizing Youth for the Red Cross: The Case of Saskatchewan, 1915-18

From 1915 onward, Saskatchewan led the country in formally enlisting young people for Red Cross work. Although the Northgate children's branch was the first to be chartered, it was joined in 1916 by chartered branches at Hoosier Consolidated School and Indian Head High School. By 1917 the province had seven fully-chartered youth branches. This grassroots growth was completely eclipsed in the following year, when Sir Richard Lake, the

\footnotetext{
${ }^{13}$ NOVA SCOTIA DIVISION (1920), Nova Scotia Red Cross During the Great War Nineteen Fourteen-Eighteen, Halifax: Canadian Red Cross Society, pp.18-19, 37, 46.
} 


\section{Sarah GLASSFORD}

province's Lieutenant Governor and President of the Saskatchewan Division of the CRCS, appealed directly to schoolchildren to help meet a million-dollar CRCS campaign goal in the spring of 1918. Many schools across the country had been contributing to the Red Cross for years, but this effort would prove to be different. Whereas the pupils of Montreal's Protestant schools, for example, were "permitted" by their school board to work for the CRCS during school hours if they or their teachers chose (MILLAR and KESHEN 2010/11: 4), and 170 British Columbia schools had raised money under their own banner for the Red Cross and Patriotic Fund campaign in 1917 (FISHER 2011: 37), the Saskatchewan Division was now embarking on a top-down drive to enlist as many child workers as possible into defined "Junior Red Cross" branches, through the schools.

In his circular letter (later followed by supportive letters from the premier and minister of education) Lake encouraged each school or class to organize itself as a Junior Red Cross branch. Rural school inspectors strongly encouraged participation, and with the added enticement of certificates for the highest school contributions, virtually every school district in the province got involved. Robert Rutherdale explains that "as instruments of the state, public school classrooms in English Canada sought to promote a unifying sense of wartime nationalism," and were not averse to allying with community organizations like the IODE $^{14}$ or the Canadian Patriotic Fund ${ }^{15}$ to do so (RUTHERDALE 2004: 212). Saskatchewan schools' embrace of the Junior Red Cross (JRC) is therefore unsurprising. On the CRCS side of the equation, the practical reason for Lake's appeal is obvious: from 1914 to 1917 schoolchildren in the province had already raised $\$ 56,074.16$ for the Belgian Children's Relief Fund and \$25,499.22 for the Canadian Patriotic Fund. The province's farm families were doing well thanks to soaring wartime wheat prices, and rural children had proven adept at channelling some of that prosperity into the coffers of two prominent war charities (SHEEHAN 1985: 69-70).

This deliberate, wide-scale, formal mobilization of children's voluntary labour for the CRCS echoed the case in Australia, where Junior Red Cross Circles were formed in two communities in New South Wales within

14 The IODE (Imperial Order Daughters of the Empire) is a women's community service organization formed in 1900 and still active today. It originally worked to promote the British Empire and Canada's place within it.

${ }^{15}$ The Canadian Patriotic Fund was created in 1914 to raise and distribute money for the support of Canadian soldiers' wives, children, and other dependents. 
months of the outbreak of war, and quickly spread. There too, Juniors were formally mobilized through their schools for Red Cross fundraising and knitting (CAMPBELL 2004: 188). The Saskatchewan approach also mirrors developments in the United States, where American Red Cross leaders sent a circular letter to the nation's schools in September 1917 encouraging the formation of Junior Auxiliaries now that the country had joined the war, and gained the support of leading educational authorities (IRWIN 2013: 260-261). Although there is no evidence that Saskatchewan CRCS leaders were aware of either the American or Australian movements, the similarities among them make it clear that during the Great War many adult Red Cross personnel - and educators - recognized children's potential as a valuable labour pool suitable for voluntary mobilization. In Saskatchewan, the trouble taken to enlist children's help paid off handsomely. The fundraising success of the 141 JRC branches for which figures were available when the 1918 CRCS annual report was printed varied from a humble 25 cent donation from the Bright branch, to the $\$ 729$ raised by Orchard School District branch ${ }^{16}$. More than 300 JRC groups were organized in Saskatchewan in 1918, and by the end of December they raised $\$ 15,195.33^{17}$ for the Red Cross (SHEEHAN 1985: 70). The Alberta Division of the CRCS picked up on the idea, and during the course of 1918 established its own JRC groups in several communities, "in conjunction with the work of the Senior Local Branches" (LENT 1947: 26).

\section{Interwar Atonement: The Canadian Junior Red Cross, 1919-39}

The success of Saskatchewan's school-based Junior Red Cross venture led the provincial Red Cross executive committee to conclude that this idea merited further development as a peacetime activity - and, in fact, that the future of the entire Red Cross in Canada might rest upon enlisting young people in the cause. Saskatchewan leaders envisioned revamping the ad-hoc wartime fundraising initiative as a complete program of health and citizenship education that would redirect children's voluntary labour toward serving the needs of other children (SHEEHAN 1985: 71). The possibilities were not lost on CRCS leaders outside Saskatchewan. At the March 1920 annual meeting, Alberta leader Mrs. C.B. Waagen proposed that the CRCS deliberately engage children and youth in the Red Cross through special Junior membership campaigns and the creation of a JRC magazine ${ }^{18}$. By the following year's annual meeting, the

\footnotetext{
${ }^{16}$ CRCS (1919), Annual Report for 1918, Toronto: CRCS, p. 144.

${ }^{17}$ Equivalent to $\$ 225,986.36$ in 2016. Bank of Canada Inflation Calculator, www.bankofcanada.ca (17 May 2016)

${ }^{18}$ CRCS (1920), Annual Report for 1919, Toronto: CRCS, p. 104.
} 


\section{Sarah GLASSFORD}

JRC as a school-based program was well underway in the three westernmost provinces, and planted in New Brunswick. Provincial Red Cross leaders consulted the Saskatchewan Division and their own local education experts as they developed the new peacetime program's structure and resources ${ }^{19}$. In 1921 teacher and registered nurse Miss Jean Browne (formerly a very active member of the Saskatchewan JRC Committee) was appointed as the national JRC director. She also served as the editor of the Canadian Red Cross Junior magazine that first appeared in April 1922.

By 1921 the JRC had 68,000 members in six provinces: Alberta, British Columbia, New Brunswick, Ontario, Quebec, and Saskatchewan (still leading the way with 40,000 of those members). That same year the CRCS annual report called the JRC "probably the most promising side of the peacetime work of the Red Cross" and "the most hopeful educational agency" among the Society's many new health promotion activities ${ }^{20}$. The peacetime JRC was not simply a Canadian organization (although the CRCS was one of several national Red Cross societies at the forefront of JRC innovation), but rather an international one, promoted by the new Paris-based League of Red Cross Societies. Although each national JRC determined its own activities, the League encouraged and coordinated the exchange of educational resources among them. All JRCs shared a motto - "I Serve" - and three core values: good health, service to others, and international friendliness/good citizenship.

The adult idealism driving CRCS investment in the peacetime JRC is apparent in the 1921 annual report's section on the JRC. "When one considers the great influence of the acts and thoughts of childhood upon after life," the Society asserted, "it will be realized what a telling power the [JRC] organization must have upon the coming generation ${ }^{21}$." Education is always about moulding young minds in directions that adults deem best, but this impulse was amplified and made more urgent in the 1920s by the appalling losses of the Great War, and the collective sense that Western civilization had somehow failed by allowing such a cataclysm to occur.

As early as 1916, there were signs that the burden of redeeming this fallen world would be placed on the younger generations. "Great numbers of the ablest and best have already fallen on the field of battle," wrote Dr. George R. Parkin in his message for Empire Day. "Their places must be supplied from

${ }^{19}$ CRCS (1921), Annual Report for 1920, Toronto: CRCS, pp. 24, 36, 39, 44, 46.

${ }^{20}$ CRCS (1922), Аnnual Report for 1921, Toronto: CRCS, pp. 5, 23, 31

${ }^{21} \mathrm{Ibid}, \mathrm{p} .31$. 


\section{ENGLISH-CANADIAN CHILDREN'S FIRST WORLD WAR RED CROSS WORK}

our schools and colleges. To make these substitutes worthy to take up the work of those who have died is the task that our teachers must keep before their eyes ${ }^{22}$." The CRCS organized its 1920 s experiments in peacetime public health work around the idea of nation-building through health, and the school-based JRC held pride of place in this agenda. Through the "Health Game" (in which students tried to uphold ten health and hygiene rules), as well as its broader health education teachings and hands-on activities, the JRC aimed to shape a more physically robust generation of citizens. The service component of the program was seen as a way to transmit one of the few redeeming features of the Great War - the spirit of service and sacrifice it inspired - while the use of parliamentary procedure in child-run JRC branches was considered hands-on training in democratic citizenship. But the program was intended to foster not only good Canadian citizenship, but also good world citizenship. Through international correspondence and portfolio exchanges with other national JRCs and internationally-focused articles in the JRC magazine, the program aimed to foster international friendship among children - an initiative explicitly set forth as a peacemaking tool, and in line with the broader cultural internationalist movement of the 1920s (IRIYE 1997: 51-90; IRWIN 2013: 255-279; VALDES 2015: 1-14). Contemporary education officials valued this element of the program in particular. Alberta Minister of Education George P. Smith asserted in 1919 that "the most important work of the Junior Red Cross would be the moral education and training in citizenship which it provides" (LENT 1947: 29).

Historian Michael Barnett sees a pattern of atonement in the periodic surges of humanitarianism that characterized the twentieth and early twentyfirst centuries. Such atonement was a "process of regeneration, purification, and restoration of a unity with humankind" after the painful recognition that this unity had been broken through distinctly un-humanitarian wartime acts (BARNETT 2011: 27). The slaughter of the First World War represented just such a crisis for the Western world, and in its aftermath the former combatants sought to repent and atone, as a memorial to the dead and a promise for the future. The Canadian JRC of the 1920s and 1930s was one such form of adult atonement. Canada's myth and memory of the Great War revolved around the belief that the war dead gave their lives willingly in order to pave the way for a better future. Completing this task by building a better Canada, and a better world, was the debt Canadians owed them (VANCE 1997: 220, 258). Within

\footnotetext{
${ }^{22}$ PARKIN, George R. (1916), “A Message for Empire Day,” The Educational Review, May, pp. 250-251.
} 


\section{Sarah GLASSFORD}

this wider cultural framework of the war's meaning, CRCS leaders understood the JRC as a forward-looking, living war memorial: the JRC would shape better children, and those children, as adults, would in turn create a healthier, more caring Canada, and a world of perpetual peace. "I always visualise that the best monument we can raise here in Canada to the men who fell in the war, is the building up of these better conditions," wrote Alberta Division's Mrs. C.B. Waagen in $1926^{23}$.

In the eyes of its creators, the JRC's potential influence was not limited to its schoolchild members. Social reformers of the interwar period viewed schools as an ideal access point not only to children themselves, but through them to the wider community. This access was particularly valued by reformers concerned not merely with conserving or enhancing child life, but also with "Canadianizing" recent immigrant populations (both rural and urban), and improving the health and hygiene practices of the urban working-classes. As Nancy Sheehan writes, "with an interest in health and citizenship, an ability to enlist support from education officials and teachers, and a program to change the curriculum," the JRC had the potential to accomplish all these goals (SHEEHAN 1985: 68-69). The JRC would mould children, and (organizers hoped) children would change their own families.

Although it gained the support of all the provincial departments of education, the JRC was only ever a voluntary program that individual classroom teachers either chose to integrate into their teaching or not. But thanks to provincial JRC organizers and the program's versatile, progressive format, the JRC steadily expanded throughout the interwar decades (SHEEHAN 1987: 250). Its growth was uneven across the country - for instance, Quebec's French Catholic school boards refused access to their schools - but by 1939 425,000 Canadian children were participating in 14,000 branches spread through every province, while another 35,000 Newfoundland ${ }^{24}$ children were affiliated with the Canadian JRC ${ }^{25}$. Few other youth organizations in the country boasted such membership or integration into classrooms.

${ }^{23}$ WAAGEN, Mrs. C.B. (1926), "An Interpretation of Red Cross," Calgary: Alberta Division CRCS, p.12, Glenbow Archives M8228/224

${ }^{24}$ Newfoundland (a separate Dominion of the British Empire until 1949) did not have its own Red Cross.

${ }^{25}$ CRCS (1939), The Canadian Red Cross Society 1914 - and After, Toronto: CRCS, p. 8, Canadian Red Cross National Archive, Box 1, File 1.I. 


\section{Mass Mobilization: The Canadian Junior Red Cross and the Second World War}

The outbreak of the Second World War posed a momentary dilemma for the Canadian JRC: after two decades of promoting peace and international friendliness among children, how would it respond to the return of the senior Red Cross to a wartime footing? In part, the organization tried to avoid engaging children directly in the political and military aspects of the war. But the older pattern of youth engagement in voluntary Red Cross war work reasserted itself, and this time the mobilization was deliberate, nation-wide, and to some extent top-down. Each child-run, classroom-based JRC branch decided on its own activities, but between teacher influence, the encouragement of provincial and national JRC directors, and the broad spirit of mobilization for total war at work in the country, it would have been very difficult for children to avoid participating in at least some form of war work. The rapid expansion of JRC enrolment after 1939 attests to the fact that many youth found the JRC an appealing venue for wartime service (GLASSFORD 2014: 222-227, 231233). The existence of an established JRC meant that young people's wartime Red Cross work was highly visible, to some extent separate from adult efforts, and substantially greater in the Second World War than in the First. By the end of 1945 Canadian children and youth had contributed over $\$ 3,000,000$ in $\mathrm{cash}^{26}$ as well as handmade goods and labour to the overall CRCS war effort (GLASSFORD 2014: 229).

\section{Conclusion}

Examining young people's Red Cross work expands the existing picture of Canada's First World War home front by showing how attitudes toward child labour and a wartime ethos that expected universal mobilization jointly drew young people into the adult work of the Red Cross. Once engaged, they played valuable roles both material and symbolic, donating time, money, and labour while bolstering the image of the war as a cause for which all citizens were keen to serve and sacrifice. The success of this ad-hoc mobilization led adults to try to harness youthful energies in a more structured fashion after the war, through a revamped and expanded Junior Red Cross program. The interwar JRC aimed to create a new, better generation of Canadian citizens - healthy, service-minded, and internationalist. Yet only two

\footnotetext{
26 Equivalent to $\$ 42,164,835.16$ in 2016. Bank of Canada Inflation Calculator, www.bankofcanada.ca (17 May 2016).
} 


\section{Sarah GLASSFORD}

decades after the peacetime JRC's creation, another generation of children was swept up in an adult-created war, and this time the voluntary labour of JRC members was deliberately mobilized in service of the wartime humanitarian cause. No doubt some of their parents flocked to the senior Red Cross in 1939 all the more quickly as a result of their own youthful involvement in the First World War. All told, the legacy of children's First World War voluntary work made itself felt in the realms of Canadian health, education, internationalism, and voluntary work well into the middle of the twentieth century. Three times between 1914 and 1945 English-Canadian children were called upon to help carry the war-related burdens of their elders, shouldering the load of voluntary war work in two global conflicts not of their own making, and bearing the weight of interwar idealism during the two decades in-between.

\section{Bibliography}

ALEXANDER, Kristine (2012), “An Honour and a Burden: Canadian Girls and the Great War," in S. Glassford and A. Shaw (eds.), A Sisterhood of Suffering and Service: Women and Girls of Canada and Newfoundland during the First World War, Vancouver: UBC Press, pp. 173-194.

BARNETT, Michael (2011), Empire of Humanity: A History of Humanitarianism, Ithaca: Cornell University Press.

BENNETT, Charlotte (2014), "Now the war is over, we have something else to worry us': New Zealand Children's Responses to Crises, 1914-1918," Journal of the History of Childhood and Youth, 7:1, pp. 19-41.

BLACK, Dan, and BOILEAU, John (2013), Old Enough to Fight: Canada's Boy Soldiers in the First World War, Toronto: James Lorimer \& Company.

CAMPBELL, Annie (2004), ““...thousands of tiny fingers moving': The Beginning of the Junior Red Cross Movement in New South Wales, 19141925," Journal of the Royal Australian Historical Society, 90:2, pp. 184-200.

CLEMENTS, Elsey V.N. (1919), The Work of the Canadian Red Cross Society in the Province of New Brunswick During the Years of the Great War, Saint John: The Saint John Globe Publishing Co. Ltd.

COOK, Tim (2008), “'He Was Determined to Go': Underage Soldiers in the Canadian Expeditionary Force," Histoire sociale/Social History, 41:81, pp. 4174. 
DALEY, Hartwell (1981), "Volunteers in Action": The Prince Edward Island Division Canadian Red Cross Society 1907-1979, Summerside: Williams \& Crue Ltd.

EASTON McLEOD, Ellen (1999), In Good Hands: The Women of the Canadian Handicrafts Guild, Montreal \& Kingston: McGill-Queen's University Press for Carleton University.

FISHER, Susan R. (2011), Boys and Girls in No Man's Land: EnglishCanadian Children and the First World War, Toronto: University of Toronto Press.

GLASSFORD, Sarah (2016), Mobilizing Mercy: A History of the Canadian Red Cross, Montreal \& Kingston: McGill-Queen's University Press.

--- (2014), "Practical Patriotism: How the Canadian Junior Red Cross and Its Child Members Met the Challenge of the Second World War," Journal of the History of Childhood and Youth, 7:2, pp. 218-242.

--- (2008), “'The Greatest Mother in the World': Carework and the Discourse of Mothering in the Canadian Red Cross Society during the First World War," Journal of the Association for Research on Mothering, 10:1, pp. 219-232.

GRAHAM, Jeanine (2008), "Young New Zealanders and the Great War: Exploring the Impact and Legacy of the First World War, 1914-2014," Paedagogica Historica, 4:4, pp. 429-444.

HUTCHINSON, John F. (1996), Champions of Charity: War and the Rise of the Red Cross, Boulder: Westview Press.

IRIYE, Akira (1997), Cultural Internationalism and World Order, Baltimore: Johns Hopkins University Press.

IRWIN, Julia F. (2013), “Teaching 'Americanism with a World Perspective': The Junior Red Cross in the U.S. Schools from 1917 to the 1920s," History of Education Quarterly, 53:3, pp. 255-279.

KENNEDY, Rosie (2014), The Children's War: Britain, 1914-1918, Basingstoke: Palgrave Macmillan.

LENT, D. Geneva (1947), “Alberta Red Cross in Peace and War (1914-1947),” unpublished manuscript, Canadian Red Cross National Archive.

LEWIS, Norah (1995), “'Isn't this a terrible war?' The Attitudes of Children to Two World Wars," Historical Studies in Education, 7:2, pp. 193-215.

MCKENZIE, Andrea (2008), "Women at War: L.M. Montgomery, The Great War, and Canadian Cultural Memory," in J. Mitchell (ed.), Storm and 


\section{Sarah GLASSFORD}

Dissonance: L.M. Montgomery and Conflict, Newcastle: Cambridge Scholars Publishing, pp. 83-108.

MILLAR, Anne, and KESHEN, Jeff (2010/11), "Rallying Young Canada to the Cause: Anglophone Schoolchildren in Montreal and Toronto during the Two World Wars," History of Intellectual Culture 9:1, pp. 1-16.

MONTGOMERY, L.M. (1921, 2010), Rilla of Ingleside, B. Lefebvre and A. McKenzie (eds), Toronto: Viking.

PALKA, Lindsey Marie (2012), “Dear Little Kiddies': Children, the Media, and the First World War in Atlantic Canada," University of New Brunswick, MA Thesis.

RUTHERDALE, Robert (2004), Hometown Horizons: Local Responses to Canada's Great War, Vancouver: UBC Press.

SHEEHAN, Nancy M. (1987), "Junior Red Cross in the Schools: An International Movement, a Voluntary Agency, and Curriculum Change," Curriculum Inquiry, 17:3, pp. 247-266.

--- (1985), “The Junior Red Cross Movement in Saskatchewan, 1919-1929: Rural Improvement Through the Schools," in D.C. Jones and I. MacPherson (eds.), Building Beyond the Homestead: Rural History on the Prairies, Calgary: University of Calgary Press, pp. 66-86.

VALDES, Annmarie (2015), "I, being a member of the Junior Red Cross, gladly offered my services': Transnational Practices of Citizenship by the International Junior Red Cross Youth," Transnational Social Review: A Social Work Journal, DOI 10.1080/21931674.2015.1038094.

VANCE, Jonathan (1997), Death So Noble: Memory, Meaning, and the First World War, Vancouver: UBC Press 